\title{
Functional development of a New Zealand weather station network to improve plant production
}

\author{
W.R. Henshall' , G.N. Hill'1, R.M. Beresford ${ }^{1}$, R.H. Agnew ${ }^{2}$, P.N. Wood ${ }^{3}$ \\ and R.R. Marshall ${ }^{4}$ \\ ${ }^{1}$ The New Zealand Institute for Plant \& Food Research Ltd, Private Bag 92-169, Auckland \\ ${ }^{2}$ The New Zealand Institute for Plant \& Food Research Ltd, PO Box 845, Blenheim \\ ${ }^{3}$ The New Zealand Institute for Plant \& Food Research Ltd, Private Bag 1401, Havelock North \\ ${ }^{4}$ The New Zealand Institute for Plant \& Food Research Ltd, 990 Earnscleugh Rd, RD 1, \\ Alexandra \\ Corresponding author: Warwick.henshall@plantandfood.co.nz
}

\begin{abstract}
For over 25 years The New Zealand Institute for Plant \& Food Research Ltd (PFR) and its antecedents have operated a network of weather stations in the main New Zealand horticultural regions. Data from these stations have been applied to the analysis of trials and surveys, and used for the development of disease models and horticultural software. Access to the data has evolved from direct links between each weather station's dial-up modem and the user's computer, to standalone MetWatch software, to the web-based MetWatch Online, and finally to the current Internet Protocol (IP)-based system allowing direct-access via smartphones. The most recent network upgrade, to provide near real-time data via the $3 \mathrm{G}$ cellular network, provides the focus for this review of the network and its applications. We discuss opportunities for future development of equipment within the weather station network.
\end{abstract}

Keywords weather stations, plant disease, data loggers, environmental data

\section{INTRODUCTION}

Weather data are widely used in plant protection and plant science. Within PFR the most common areas for use of weather data are in sustainable fruit and crop production, for example Hall \& Snelgar (2008), and crop protection, for example in low-pesticide production (Agnew et al. 2004; Beresford 2010; Walker et al. 2015). This paper describes the network of weather stations owned by PFR, which are situated both on PFR research orchards and on private orchards, and the use of these data in plant disease research and management. The origins of the PFR weather station network go back to when the New Zealand Meteorological Service received daily readings, taken at 9am, from stations around the country. In 1984 there were more than 300 such stations. Most of the current PFR research orchard sites were included, from Kerikeri in the north through to Clyde in the south, as well as some secondary field sites (e.g. Kumeu), which have since closed. For many scientists working on plant disease forecasting, daily recordings were not sufficiently detailed, so a number began making their own hourly recordings adjacent to field trials. By the late 
1980s a network of basic weather stations had been set up in Canterbury orchards for apple disease work (Beresford \& Spink 1992), followed by a similar network in Hawke's Bay. Meteorological Service stations complied with World Meteorological Organisation (WMO) specifications, which required the weather instruments to be sited in an open area away from buildings and shelter, so were not typical of an orchard environment.

In the early 1990s, as part of a comprehensive reorganisation of science, the functions of the Meteorological Service were split between a State Owned Enterprise MetService, which focussed on providing forecasts, and a Crown Research Institute (CRI) the National Institute of Water and Atmospheric Research (NIWA), which focused on climate science. None of the former Department of Scientific and Industrial Research regional orchard weather stations was required by MetService for forecasting, so most were automated by the CRI HortResearch to provide both continuity and the hourly data that were increasingly required. Under an ongoing contractual arrangement NIWA took over the maintenance and calibration of five HortResearch weather stations in the main horticultural regions of New Zealand. NIWA data are accessible through their climate database Cliflo (http://cliflo.niwa.co.nz/).

\section{NETWORK DEVELOPMENT Orchard 2000 and Metwatch}

A proposal for a PC-based decision-support aid for New Zealand growers was published in 1990 (Manktelow \& Laurensen 1990) with hourly weather data obtained automatically from local on-orchard weather stations. A number of these stations were set up (Beresford \& Spink 1992), and the development of Orchard 2000 software (Atkins et al. 1992) allowed the data to be used in a variety of applications. Trevor Atkins set up his own decision support company Hortvision in 1990, and in 1992 he was joined by Andrew Hodson, and their company HortPlus Ltd marketed Orchard 2000 to growers. Initially growers ran the software on their own home computers and from this evolved HortPlus MetWatch Online, with the applications and database stored on the HortPlus server. Many of these applications are products of the close association between PFR and HortPlus.

\section{Technological changes}

Since automation many of the sensors used in research-level weather stations have changed very little: thermistors used for temperature, the surface wetness sensor, the tipping bucket rain gauge, the electrical pulse anemometer, the potentiometer wind vane, and the silicon solar cell.

However, there have been changes in relative humidity measurement. Twenty-five years ago the orchard weather stations either did not record humidity, or else they used separate wet and dry bulb thermistors to calculate humidity. Since then electronic humidity sensors have become more economical and more accurate at high humidity, which is important for plant disease models.

Originally the weather stations all had a dedicated telephone landline and analogue modems. Landlines are very reliable, but they require the weather station be located reasonably close to the copper network and are prone to damage from farm equipment. At the more remote sites, GSM cellular modems were introduced, with occasional communication problems, due mainly to inadequate cellular coverage. In a recent PFR weather station network upgrade, modems were changed over to the $3 \mathrm{G}$ network (third generation) allowing a continuous data connection and a higher data transfer rate than GSM, although this is not a major requirement for PFR weather stations. The main reason for the change was to keep up with continual system upgrades to cellular networks, which are making older technology such as GSM obsolete.

\section{The current network}

There are currently 31 weather stations in the PFR network, including five at PFR research orchards that are maintained to WMO standard and calibrated by NIWA (Figure 1). The 26 other stations are generally on commercial orchards, 
located adjacent to trees or vines but sufficiently far away to avoid disruption from orchard operations such as pruning and spraying. Within the overall criterion of being located in horticultural areas, the siting of orchard weather stations depends on a number of factors. Not least is the willingness of individual growers to allow the operation of a weather station on their property over an extended period of time. The distribution of stations in a given region may also reflect grower choice of decision support provider, as weather data are available from networks other than the PFR network.

During an upgrade from August 2015 to March 2016, most PFR sites were equipped with CR200X data loggers (Campbell Scientific Inc., Logan, UT, USA) while sites with a greater number of sensors received the larger CR1000 loggers. Communication is maintained with $3 \mathrm{G}$ M2M modems (NetComm Wireless Ltd, Sydney, NSW, Australia), each with a fixed IP address

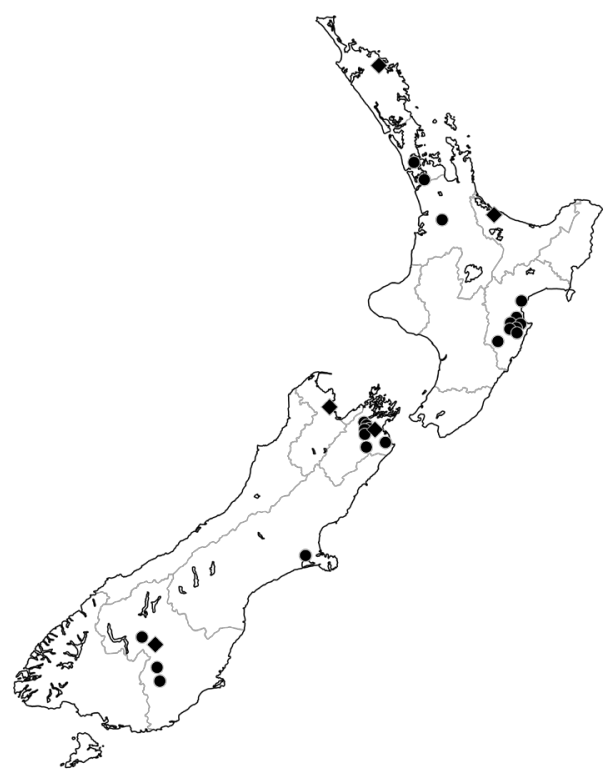

Figure 1 Plant \& Food Research Ltd (PFR) weather station network. The 31 weather stations are owned by PFR. Some stations are maintained and calibrated by PFR (circles) and some by the National Institute of Water and Atmospheric Research (diamonds). allowing internet access. Data can be downloaded to a smartphone (LoggerNet Mobile Connect; Campbell Scientific). At the sites with CR1000 data loggers, air temperature and humidity continue to be measured with HMP45A probes (Vaisala Oyj, Helsinki, Finland). At other sites a digital probe (CS215; Campbell Scientific) measures temperature and humidity at the SDI-12 input, freeing up two single-ended analogue channels. This is an advantage where the number of available channels is limited, as it is with the CR200X data loggers. Other sensors remain unchanged: rainfall (TR-525M; Texas Electronics, Dallas, TX, USA), wind direction (W200P; Vector Instruments, Rhyl, Wales, UK), and wind speed (A101M or A101R; Vector Instruments). A leaf wetness sensor (237-L; Campbell Scientific), which is not part of NIWA's WMO-standard weather stations, is included at PFR sites because of the importance of leaf wetness in disease models.

\section{Data storage and management}

When individual scientists created their own data logger records there was little need for supporting information to be included in the logger output file. A typical output file, comprising columns for date/time and the measured variables, with one row per hour, would have column headings added in the user's spreadsheet. With more widespread access through a central database some additional information such as a site code was included in the raw data. The recent upgrade further improved data management practices by using fully descriptive variable names, and by including more site information, such as GPS coordinates, in the logger output tables. All raw data output columns also have a descriptive heading. This encourages file sharing as raw data are more easily interpretable by a variety of users.

\section{APPLICATIONS Extension}

Data from PFR's orchard weather stations have been used in wine industry to control diseases better. Over the past 20 years PFR's Marlborough 
vineyard weather stations have been used for grape disease management (Agnew 2006). Weather and grapevine phenological data are now collected from the five main New Zealand wine regions; Gisborne, Hawke's Bay, Marlborough, Waipara and Central Otago. These data are summarised and reported to the wine industry on a weekly basis, through the VineFacts Newsletter that is available to subscribers on the New Zealand Winegrowers website (Agnew et al. 2015). For pipfruit, crop management aids including spray information are available through the Pipfruit New Zealand website, which also provides a custom version of Metwatch Online.

\section{Development of disease models}

PFR and its legacy organisations have made use of weather data from both the PFR and NIWA networks to develop a range of disease risk models subsequently delivered to horticultural industries through various extension pathways. One of the first models was for apple black spot (Beresford \& Spink 1992; Laurenson \& Manktelow 1992) using well established infection criteria, with ascospore release prediction (Beresford 1999) and tissue susceptibility (Beresford et al. 2004) added subsequently. Another long-established disease model, for potato late blight, has been modified for local conditions (Henshall \& Beresford 2004). In a further application of overseas derived infection criteria, the value of the MARYBLYT ${ }^{\mathrm{Tm}}$ model in the management of fire blight of apple was determined using data from Waikato and Hawke's Bay weather stations (Gouk et al. 1996), while the Downcast model for onion downy mildew was used to compare the potential for disease in Canterbury and South Auckland over several seasons (Whiteman \& Beresford 1998). A disease forecaster for elsinoe spot of apple developed using locally-derived infection criteria provided the model for illustrating receiver operating characteristic curve (ROC) analysis for calibrating risk forecast models (Beresford et al. 2015). ROC analysis provides information on model performance as the threshold of a risk indicator is varied.

The availability of data from the PFR weather station network enabled the rapid development of models for new plant diseases, such as Pseudomonas syringae pv. actinidiae (Psa) in kiwifruit (Beresford \& Tyson 2014), and for the modification of existing models to make use of changing technology. Concerns over problems with leaf wetness sensors have led to attempts to substitute relative humidity, which is included worldwide in WMO weather stations, for leaf wetness in some models (e.g. Rowlandson et al. 2015).

\section{FUTURE OPPORTUNITIES}

The PFR weather station network provides a resource in the main New Zealand horticultural areas for both research and extension applications. While the recent station upgrades focussed on data loggers and communications, there may be opportunities for installing newer sensor types as well. Examples include an acoustic sensor for rainfall measurement and an instrument that measures wind speed and direction from transit times of an ultrasound signal (Vaisala Oyj). Both instruments have no moving parts which reduces maintenance when compared with the current equipment that uses a tipping bucket rain gauge and rotating cup anemometer.

There are several advances in data handling and presentation which, although not currently implemented on the MetWatch Online website, have potential for development. The major horticultural areas are reasonably well covered by local weather stations, but there are other sites well away from stations where weather data would be useful for improving crop management. An alternative to installation of new weather stations is the interpolation of weather data from existing stations, for sites without stations. Kim et al. (2007) discuss the use of estimates of weather variables in assessment of disease risk, and later assess the economic value of such an approach (Kim et al. 2008). At a broader level more generalised datasets can be used in biosecurity risk assessments (e.g. Kim \& Beresford 2009) and climate change impact 
assessments (e.g. Beresford \& McKay 2012).

Although it is important to keep up with new technologies and data management techniques, it is also necessary to weigh up the benefits of these with the need for uninterrupted historical data records and adherence to calibration standards. This trade-off between modernisation and continuity will be the primary consideration for all future upgrades to the PFR weather station network.

\section{ACKNOWLEDGEMENTS}

The authors thank Brent Fisher for assistance with the Hawke's Bay weather station upgrade.

\section{REFERENCES}

Agnew RH 2006. Vineyard weather stations in Marlborough and their role in grape disease management. New Zealand Plant Protection 59: 378.

Agnew RH, Mundy DC, Balasubramaniam R 2004. Effects of spraying strategies based on monitoring disease risk on grape disease control and fungicide usage in Marlborough. New Zealand Plant Protection 57: 30-36.

Agnew RH, Raw V, Bishell R, Grab F, Sorenson I, Marshall RR, Wood PN, Stanley J, Gandell M, Parker A 2015. Grapevine growth stage monitoring for prediction of of phenological events. New Zealand Winegrower 93: 136137.

Atkins TA, Laurenson MR, Mills TM, Ogilvie DK 1992. Orchard-2000 - towards a decisionsupport system for new-zealand orchard industries. Acta Horticulturae 313: 173-182.

Beresford RM 1999. Validation of an ascospore release prediction model for apple black spot (Venturia inaequalis). Proceedings of the Fifty Second New Zealand Plant Protection Conference: 148-152.

Beresford RM 2010. Towards reduced reliance on fungicides for disease control in $\mathrm{New}$ Zealand's crop-based industries. New Zealand Plant Protection 63: 138-144.

Beresford RM, McKay AH 2012. Climate change impacts on plant diseases affecting $\mathrm{New}$ Zealand horticulture. Report prepared for Ministry for Primary Industries, September
2012. MPI Technical Paper No: 2013/03. PFR SPTS No. 7532. 63p. (http://www.mpi. govt.nz/document-vault/4085) accessed 13/04/2016.

Beresford RM, Spink M 1992. A national disease forecasting system for apple black spot (Venturia inaequalis) in New Zealand. Acta Horticulturae 313: 285-296.

Beresford RM, Tyson JL 2014. Seasonal accuracy of the Psa risk model. New Zealand Kiwifruit Journal Issue 283: 18-19.

Beresford RM, Henshall WR, Palmer JW 2004. A new apple scab risk model that integrates ascospore release, infection risk and susceptible leaf area. New Zealand Plant Protection 57: 20-24.

Beresford RM, Wood PN, Fisher BM 2015. Use of receiver operating characteristic curve analysis for calibrating plant disease risk forecasting models. In: Beresford RM, Froud KJ, Kean JM, Worner SP eds. The plant protection data tool box. New Zealand Plant Protection Society. Pp. 33-43.

Gouk SC, Boyd RJ, Hutchings SO 1996. Applications of the MARYBLYT computer model for identifying infection risk for fire blight of apple. Proceedings of the 49th New Zealand Plant Protection Conference: 96100.

Hall A, Snelgar B 2008. Temperature effects on kiwifruit dry matter at harvest. Acta Horticulturae 803: 155-162.

Henshall WR, Beresford RM 2004. Adaptation of potato late blight prediction models for $\mathrm{New}$ Zealand. New Zealand Plant Protection 57: 25-29.

Kim KS, Beresford RM 2009. Use of geographic information systems and satellite data for assessing climatic risk of establishment of plant pathogens. New Zealand Plant Protection 62: 109-113.

Kim KS, Beresford RM, Henshall WR 2007. Prediction of disease risk using site-specific estimates of weather variables. New Zealand Plant Protection 60: 128-132.

Kim KS, Beresford RM, Henshall WR 2008. A cost-loss analysis to evaluate the value of 
weather estimates as inputs to a disease risk model. New Zealand Plant Protection 61: 296-300.

Laurenson MR, Manktelow DW 1992. Monitor - a computer-based tool for monitoring apple black spot infection periods. Acta Horticulturae 313: 197-204.

Manktelow DW, Laurenson M 1990. Development of a decision aid for pest and disease management in fruit crops. Proceedings of the 43rd New Zealand Weed and Pest Control Conference: 114-116.

Rowlandson T, Gleason M, Sentelhas P, Gillespie T, Thomas C, Hornbuckle B 2015. Reconsidering leaf wetness duration determination for plant disease management. Plant Disease 99: 310-319.
Walker JTS, Park NM, Butcher MR 2015. Apple Futures: New Zealand's low pesticide residue apple production programme. New Zealand Plant Protection 68: 282-290.

Whiteman SA, Beresford RM 1998. Evaluation of onion downy mildew disease risk in New Zealand using meteorological forecasting criteria. Proceedings of the 51st New Zealand Plant Protection Conference: 117-122. 